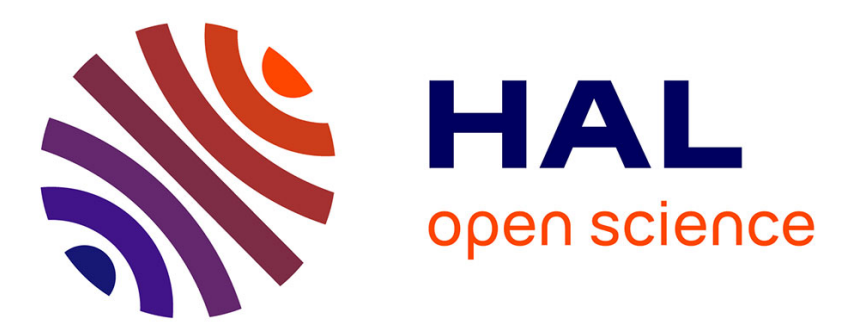

\title{
Antiarrhythmic Drugs Are not the Only Option in Electrical Storm: Extracorporeal Membrane Oxygenation as a Life-saving Alternative
}

Raphaël P Martins, Erwan Flecher, Solène Le Pennec-Prigent, Vincent Galand

\section{- To cite this version:}

Raphaël P Martins, Erwan Flecher, Solène Le Pennec-Prigent, Vincent Galand. Antiarrhythmic Drugs Are not the Only Option in Electrical Storm: Extracorporeal Membrane Oxygenation as a Life-saving Alternative. Revista Española de Cardiología (English version), 2019, 72 (2), pp.184. 10.1016/j.rec.2018.08.007 . hal-01880046

\section{HAL Id: hal-01880046}

\section{https://hal-univ-rennes1.archives-ouvertes.fr/hal-01880046}

Submitted on 7 Dec 2018

HAL is a multi-disciplinary open access archive for the deposit and dissemination of scientific research documents, whether they are published or not. The documents may come from teaching and research institutions in France or abroad, or from public or private research centers.
L'archive ouverte pluridisciplinaire HAL, est destinée au dépôt et à la diffusion de documents scientifiques de niveau recherche, publiés ou non, émanant des établissements d'enseignement et de recherche français ou étrangers, des laboratoires publics ou privés. 
Antiarrhythmic Drugs Are not the Only Option in Electrical Storm:

Extracorporeal Membrane Oxygenation as a Life-saving Alternative

Raphaël P. Martins, a,b,c,* Erwan Flecher, a,b,c

Solène Le Pennec-Prigent, ${ }^{\mathrm{a}, \mathrm{b}, \mathrm{c}}$ and Vincent Galand ${ }^{\mathrm{a}, \mathrm{b}, \mathrm{c}}$

aniversité de Rennes, Rennes, France

${ }^{\mathrm{b}}$ Service de Cardiologie, Centre Hospitalier Universitaire de Rennes,

Rennes, France

'Institut National de la Santé et de la Recherche Médicale (INSERM), U1099, Rennes, France

\section{Letter to the Editor}

Los fármacos antiarrítmicos no son la única opción en la tormenta eléctrica: El oxigenador extracorpóreo de membrana es una alternativa

\section{To the Editor,}

We read with great interest the scientific letter by García Carreño et al. ${ }^{1}$ published in Revista Española de Cardiología. In that study, the authors retrospectively analyzed their patients who underwent venoarterial extracorporeal membrane oxygenation (VA-ECMO) implantation in the context of electrical storm. Seven patients were included, all but 1 with ischemic heart disease. Following VA-ECMO implantation, 4 patients had a ventricular tachycardia ablation procedure and 2 died. The median duration of support was 9 days. The authors conclude that VA-ECMO support should be systematically evaluated in patients with refractory ventricular tachycardia and cardiogenic shock since it ensures hemodynamic support in these critically-ill patients, allowing VT ablation to be safely performed.

We completely agree with these statements. Indeed, we recently published a similar study including 26 patients with refractory electrical storm and cardiogenic shock implanted with a VA-ECMO. ${ }^{2}$ Interestingly, stable sinus rhythm was immediately obtained after VA-ECMO implantation in two-thirds of the patients and occurred after a median time of 3 hours for the remaining ones. Fifty percent of the patients eventually died, none due to the VA-ECMO, but mostly due to multiple organ failure. The average duration of VA-ECMO support was $6.7 \pm 3.6$ days. Of note, survival was significantly better in patients with repetitive ventricular tachycardia/fibrillation alternating with periods of sinus rhythm at the time of VA-ECMO implantation than in those with refractory ventricular fibrillation. To the best of our knowledge, our study is the largest database of VA-ECMO implantation in patients with electrical storm published thus far.

Our results had an impact in the field of intensive care medicine, but had less effect in cardiology, since cardiologists, and especially electrophysiologists, are more likely to attempt multiple antiarrhythmic therapies, perform electrical cardioversions, and consider ablation, rather than call interventional cardiologists or surgeons to implant a VA-ECMO for an arrhythmic problem. This reluctance probably explains why VA-ECMO is an underused device in patients with electrical storm. Patients end up dying from multiple organ failure, as a consequence of suboptimally managed electrical storm, while the complications of VA-ECMO are rare, as demonstrated by García Carreño et al. ${ }^{1}$ and by our study. ${ }^{2}$ Physicians should keep in mind that in patients with intractable electrical storm and cardiogenic shock refractory to usual management, VA-ECMO provides efficient hemodynamic support and helps to rapidly restore sinus rhythm, probably due to rapid improvement of myocardial perfusion and a decrease in left ventricular end-diastolic pressure.

The evidence supporting the use of VA-ECMO in electrical storm is scarce and is especially focused on the use of VA-ECMO during ventricular arrhythmia ablation and not as an adjunctive therapy per se.,4 Thus, we congratulate Revista Española de Cardiología for showing interest in this topic and the authors for once again demonstrating that electrical storm can, of course, be managed pharmacologically and by ablation, but also by VA-ECMO implantation, since it might provide successful outcomes, preventing secondary organ damage and maintaining sufficient cardiac unloading.

* Corresponding author:

E-mail address: raphael.martins@chu-rennes.fr (R.P. Martins).

\section{REFERENCES}

1. García Carreño J, Sousa-Casasnovas I, Vicent Alaminos ML, Atienza Fernández F, Martínez Sellés M, Fernández Avilés F. Extracorporeal Membrane Oxygenation in Patients With Electrical Storm: A Single-center Experience. Rev Esp Cardiol. 2018. http://dx.doi.org/10.1016/j.rec.2018.07.001.

2. Le Pennec-Prigent S, Flecher E, Auffret V, et al. Effectiveness of Extracorporeal Life Support for Patients With Cardiogenic Shock Due T o Intractable Arrhythmic Storm. Crit Care Med. 2017;45:e281-e289.

3. Baratto F, Pappalardo F, Oloriz T, et al. Extracorporeal Membrane Oxygenation for Hemodynamic Support of Ventricular Tachycardia Ablation. Circ Arrhythm Electrophysiol. 2016. 9:pii: e004492.

4. Tsai FC, Wang YC, Huang YK, et al. Extracorporeal life support to terminate refractory ventricular tachycardia. Crit Care Med. 2007;35:1673-1676.

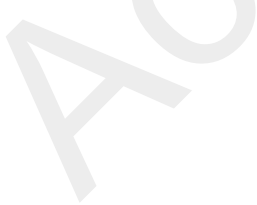

